\title{
Teaching Experience and Need for Instructional skills
}

\author{
Hoda Rezaeian and Narges Nazari \\ (Universiti Putra Malaysia, Malaysia) \\ doi:10.7575/aiac.alls.v.3n.2p.87
}

\begin{abstract}
The relationship between working experience and need for instructional skills is of major importance for the teaching and learning process. It seems teachers need to develop their teaching methods inside the class in order to activate students to learn more effectively. The researchers decided to find out if there is any relationship between working experience and need for instructional skills. The data was obtained

from more than 31 randomly chosen lecturers through questionnaire from the Faculty of Educational Studies at University Putra Malaysia. From the results, it was concluded that there is no relationship between years of working experience and need for instructional skills.
\end{abstract}

\section{Introduction}

Every lecturer has his own way of teaching. They all teach but how successful they are and how they can be more successful in conducting the class is to a great extent the central reason for this research to find out if there is actually any relationship between need for professional development with regards to instructional skills and year of teaching experience. It seems that the teachers need to develop their teaching methods inside the class in order to engage students to a better learning to learn more effectively and successfully. The researcher begins this research since there is a constructed feeling that there is a need for professional growth, instructional skills and teaching skills for teachers regardless of the years of working experience. Researchers, in general, know a little about the evolution of teaching skills. When the lecturers feel the necessity for instructional skills, they try to manage the professional growth and frequently, the professional growth of the lecturers are through workshops and training programs organized by the deans of faculties.Cognitive research has shown that a significant number of individuals have learning styles best served by pedagogical techniques other than lecturing. Therefore, a thoughtful and scholarly approach to skillful 
teaching requires that faculty members become more knowledgeable about the many ways strategies promoting active learning have been successfully used across the disciplines. On the other hand, it seems that each faculty member should engage in self-reflection, exploring his or her personal willingness to experiment alternative approaches for instruction.

Commonly, lecturers serve as students' need diagnosticians, lessons and learning strategies planners, learning facilitators, and learner performance assessors. Increasingly, lecturers participate in university-based governance and decision making (Bauch \& Goldring, 1998; Wall \&Rinehart, 1998). They also help determine how to allocate human and fiscal resources to meet student needs and assist in the development of curriculum content and activities (Fitzharris,1999; Trzcinka, 1998). It goes without saying that when they think about updating their instructional skills, they can have better demonstration styles for teaching. Lecturers need some competencies which they must acquire including maintaining language skills, building awareness of the target culture education, using technology, teaching students with special needs, practice of research methodology, assessing students, practice of teaching methodology, improving the classroom management skills, using cooperative learning, planning lessons and units and so on. The researcher plans to investigate if experienced lecturers feel the necessity and need to attain teaching skills.

\section{Definition of key term}

\section{Professional development}

Professional development refers to skills and knowledge attained for both personal development and career advancement. Professional development encompasses all types of facilitated learning opportunities, ranging from college degrees to formal coursework, conferences and informal learning opportunities found in practice. It has been described as intensive and collaborative, ideally incorporating an evaluative stage. There are a variety of approaches to professional development, including consultation, coaching, communities of practice, lesson study, mentoring, reflective supervision and technical assistance.

A wide variety of people, such as teachers, health care professionals, lawyers, accountants and engineers engage in professional development. Individuals may participate in professional development for the lifelong learning, sense of moral obligation, maintaining and improving professional competence, enhancing career progression, keeping abreast of new technology and practice, or to comply with professional regulatory organizations. 
Professional development may include formal types of vocational education, typically postsecondary or poly-technical training leading to qualification or credential required to obtain or retain employment. Professional development may also come in the form of pre-service or in-service professional development programs which may be formal, or informal, group or individualized. Individuals may pursue professional development independently, or programs may be offered by the departments.

\section{Background}

It will be wise to notice that just a few graduates have the expertise for their jobs. It can be proven by taking a sneak peek into the market. Often lecturers believe that their working experience is sufficient to teach, train students, run the class, be effective, be encouraging, be productive and fruitful, i.e. they are skillful and experienced enough to teach effectively and appropriately and they do not need any development in their jobs. It is clear that, the teachers contribute directly to the growth of students. Teachers are the trainers. Therefore, they should develop their skills and refresh themselves with regards to their knowledge and try to impart their educational and instructional skills. If a teacher is not well trained, how is $\mathrm{s} /$ he to train well?

Professional development is a broad term, encompassing a range of people, interests and approaches. Those who engage in professional development share a common purpose of enhancing their ability to do their work. At the heart of professional development is the individual's interest in lifelong learning and increasing their own skills and knowledge.

\section{Statement of the problem}

People are different and so are faculty members. Some faculty members have more effective instructional skills over others. It seems that faculty members with more working experience do not feel the necessity of professional development.

Teachers and lecturers may be having many years of teaching experience but instructional skills may not have improved or developed parallel to that of teaching years. Teachers need to update their knowledge to become more effective trainers in the course of training trainees.

In reference to discussions the researchers have had with selected university students, there was mention of weaknesses in lecturers' instructional skills. The researchers decided to have 
a closer look at this problem and investigate whether there is any tangible and significant relationship between years of teaching experience and need for instructional skills.

\section{Research question}

This study answers the following question:

Is there any significant relationship between the working experience of faculty members and the need for professional development with regard to instructional skills?

\section{Hypothesis}

It is hypothesized that there is no significant relationship between the working experience of faculty members and need for professional development regarding instructional skills.

\section{Objectives of this study}

The objective of this study is to investigate the extent to which faculty members with more experience feel the need to improve their current instructional skills. Each faculty member explores his or her personal willingness to experiment with alternative instructional skills in relation to his or her work experience.

\section{Significance of the study}

The instructional skills can facilitate the teachers' pedagogic growth and students' understanding of the specific field. The development of teachers' teaching skills seems to be a major content area. They must update their knowledge and their teaching methods in order to be more successful in imparting their knowledge to the students.

The effects of these instructional skills create a culture characterized by professional collaboration and professional learning. The principals of the university can set up some courses for the teachers to improve their skills so that the students' competency increases in the classes and in this way they will be better in their fields.

\section{Limitation of the study}

The researchers could not do this research in all faculties due to insufficient time. On the other hand, some lecturers actually did not cooperate much as they were too busy to spare time to study the questionnaire and answer and were not willing to help the researchers. 


\section{Review of literature}

Instructional skills include: maintaining language skills, building awareness of the target culture or multicultural education, using cooperative learning, improving classroom management skills, planning lessons and units, using technology, teaching students with special needs, theoretical issues of teaching methodology, practice of teaching methodology, practice of research methodology and assessing the students.

At the heart of all these is the matter of interaction, with good instructional leaders realizing that "most teachers expand their teaching range only with carefully designed support and assistance" (Blasé and Blasé, 1998).

In the 1980s, researchers began to focus on teacher behavior, learning-to-teach studies focused on the cognitions, beliefs, and mental processes that underlie teachers' classroom behavior.

Therefore, a thoughtful and scholarly approach to skillful teaching requires that faculties become more knowledgeable about the many ways strategies promoting active learning have been successfully used across the disciplines. Further, each faculty member should engage in self-reflection, exploring his or her personal willingness to experiment with alternative approaches to instruction.

Generally, teachers agree that their preparation has been inadequate and that the current system of in-services is inadequate as well. Education reform is putting unprecedented pressure on teachers hoping to improve the educational system." The growing realization that professional development practices are badly out of sync with the reform agenda is spurring widespread interest in rethinking teachers, on-the-job learning(Bradley,1996,p.8).

It is not far beyond believing that the lecturers and teachers or everyone whose job is related to teaching must update his or her own information and instructional skills since science is growing rapidly and, on the other hand, new methods of teaching are happening to be. Students' needs for their future jobs and being able to use the latest technology in teaching are now becoming a necessity. 
This issue is not due to the teachers' teaching experiences. According to Azin-Manley, Sachse, and Olson (1996), the more staff development teachers received, the more likely they were to feel that fellow staff members could deliver high quality curriculum. Some teachers are experienced instructionally but they feel isolated and segregated. They have the feeling that they do not have any development in their jobs as teachers. They feel bored and abolished persons. In particular, there are variables pertaining to joint, collaborative work between teachers which are positively related to feelings of confidence in the abilities of fellow staff members.

In general, as Azin-Manley. mentioned in his study, teachers who have the opportunity to observe and work with one another generally find their colleagues to be knowledgeable and capable (pp.69-70).

Albert Shanker, the late president of the American Federation of Teachers (AFT), called for unions to take on a larger role in teacher training and retraining. He said that "newer members look to the union and expect it to pay as much attention to their professional needs as to the bread-and-butter issues" (as cited in Ponessa, 1996, p.16). Many teachers are observed to be skillful and experienced, but they also feel the need to attend some courses and workshops to gain more knowledge of instruction and learn how to be more effective and active teachers.

In a research by Kinser, Elliot, Foster, Convington, King and Liou (1998) which was carried out among teachers with different teaching experiences; vocational teachers (12.5years working experiences), academic teachers (17years) and others (14years), it was found that teachers wanted to learn more teaching strategies and discipline specific updates from colleagues who have experience with the strategies in the classroom. This study supports the notion that teachers want to learn more about teaching strategies and instructional skills and discipline specific updates and need time to work with colleagues since they are believed to be able to learn from each other.

Teachers reflect because they want to improve their teaching skills. A number of researchers state the importance of reflective practice. As a result of engaging in a reflective process, individuals acquire knowledge and understanding (Clarke\& Kelly, 1996; Schön, 1983), learn from their experiences (Kolb, 1984; Schön, 1983), apply knowledge as a result of engaging in a reflective process, individuals acquire knowledge and understanding (Clarke\& Kelly, 1996; 
Schön, 1983), to practice while being coached by professionals in the discipline (Schön, 1996), and explore assumptions they bring to the workplace (Brookfield, 1995). As reflective practitioners, teachers gain a deeper understanding of their teaching approaches and effectiveness as teachers.

In different studies where novice teachers and professional teachers are compared, it is obvious that novice teachers do not have much experiences, but they really want to be professional and experienced. They like to be students of teachers' training courses. The expert teachers are those whose teaching experiences have developed throughout years of teaching and practice. However, it is not easy to identify expert teachers since expertise is not all about years of teaching experience or does not depend on duration of practice at schools or institutes but also on the process of learning from experience. If a teacher is not learning from the experiences and the situations s/he is every day facing with, s/he won't be an experienced and skillful teacher. As John Dewey (1933) pointed out, experience could be educative or 'miseducative'. There is no guarantee that a teacher who teaches from day to day in a similar way, without reflection, improves professionally and will become skillful.

The teachers mostly enjoy being free to implement the changes that they want. Doing so, they will be involved in changes that will have impact on classrooms as well as their own.

The early years of teaching is a special time in a teacher's career, different from what has been done before and what will come after. No longer student-teachers in someone else's classroom. Novice teachers are on their own, facing the same responsibilities, difficulties, functions, roles, leadership, control and power as their experienced colleagues.

There are evidences that engaging in professional development activities is related to quality of students' learning. The more a teacher is skillful in terms of instruction, the higher the chances are for the students to learn. While years of teaching experience is correlated to better student learning, it cannot be said that the more experienced a teacher is the better s/he will be in teaching. Looking back, one could be sure that we all have memories of terrible teaching we have endured from very experienced teachers. Conversely, many of us would have participated in highly engaging and valuable learning led by inexperienced but highly committed teachers which proves that being good at instructional skills is not related to years 
of teaching experience and novice teachers can be more successful that a highly experienced one at times.

Layfield and Dobbins (2002) and Washburn, King, Gartan and Harbstreit (2001) reported that experienced teachers need in-service preparation in using computers and other multi-media equipment. Additionally, Dormody and Torres (2002), who examined teachers with 10 years of teaching experience or less, reported that the competency needing the most in-service preparation for both beginning and tenured teachers was using computer technology in the classroom. Edwards and Briers (1999) and Peiter, Terry and Cartmell (2003), who specifically studied newer teachers, also believed preparation was needed in computerassisted instruction and implementing other new technologies. Joerger's (2002), assessment of two consecutive years of agricultural education graduates listed teaching about technological advancements in agriculture as an important in-service need, and Kotrlik, Redmann, Harrison, and Handley (2000) reported about agriculture teachers' inadequacies in general and software specific knowledge and skills. In addition to integrating agricultural technology, researchers have reported other technical agriculture competencies needed by agriculture teachers, such as teaching agricultural mechanics, soil science (Baker \& Malle, 1995), and biotechnology (Washburn, King, Gartan and Harbstreit, 2001).Developing an effective public relations program was a highly rated in-service need of both beginning and experienced teachers, according to Garton and Chung (1996) and Layfield and Dobbins(2002).

Understanding student evaluation is another documented teacher preparation need (Layfield \& Dobbins, 2002; Roberts \& Dyer, 2002). In fact, South Carolina beginning teachers needed in-service help with developing performance-based assessments of their students (Layfield \&Dobbins, 2002), and Roberts and Dyer (2002) reported that competency in all types of student evaluation was an imperative skill for future teachers.

\section{Methodology}

Sample

Data were obtained from more than 31 lecturers from various programs in the Faculty of Educational Studies (FPP) in University Putra Malaysia and they were chosen randomly. The lecturers were from different majors: counselling, TESL, curriculum, sport science, ICT in education, HRD, agricultural education, educational psychology and exercise science. 


\section{Instrument, Data Analysis and Procedure}

The questionnaires were distributed at the Faculty of Educational Studies (FPP) in University Putra Malaysia. The questionnaires were given to the lecturers and all were collected within 1 week. For this research, Likert scale was used in questionnaires and for the analysis of data the Statistical Package for Social Sciences (SPSS) software was employed (ONE-WAY ANOVA).

\section{Findings}

To find out the results, the researchers added up 11 items of each questionnaire and calculated the mean. The one way ANOVA and the test of homogeneity of variance was calculated as well. Levene statistic revealed that assumption of homogeneity of variance was met so one way ANOVA was appropriate for analysing this data. What the researchers came up with are as follows:

Table 1: Test of homogeneity of variances (instructional skills)

\begin{tabular}{cccc}
\hline Levene Statistic & df1 & df2 & Sig. \\
\hline .191 & 4 & 26 & .941
\end{tabular}

$F(4,26)=0.612, p=0.658$

It was supposed that probability equals with 0.05 .

Table 2: ANOVA (instructional skills)

\begin{tabular}{cccccc}
\hline & Sum of Squares & df & Mean Square & F & Sig. \\
\hline Between Groups & 225.700 & 4 & 56.425 & .612 & .658 \\
Within Groups & 2396.300 & 26 & 92.165 & & \\
Total & 2622.000 & 30 & & & \\
\hline
\end{tabular}

The analyses proved that the instructional skills had the normal distribution. The mean showed to be 4 and SD was 9.35. Skewness and Kurtosis were 0.23 and 0.797 respectively. Therefore, it can be concluded that the assumption normality of distribution has been met and Scatter Plot shows that the two variables do not have any relationship with each other. According to table 2, sig-t is 0.658 which is more than 0.05 and therefore can be concluded that the null hypothesis is rejected. 
As mentioned earlier, there is no significant relationship between working experience and need for instructional skills.

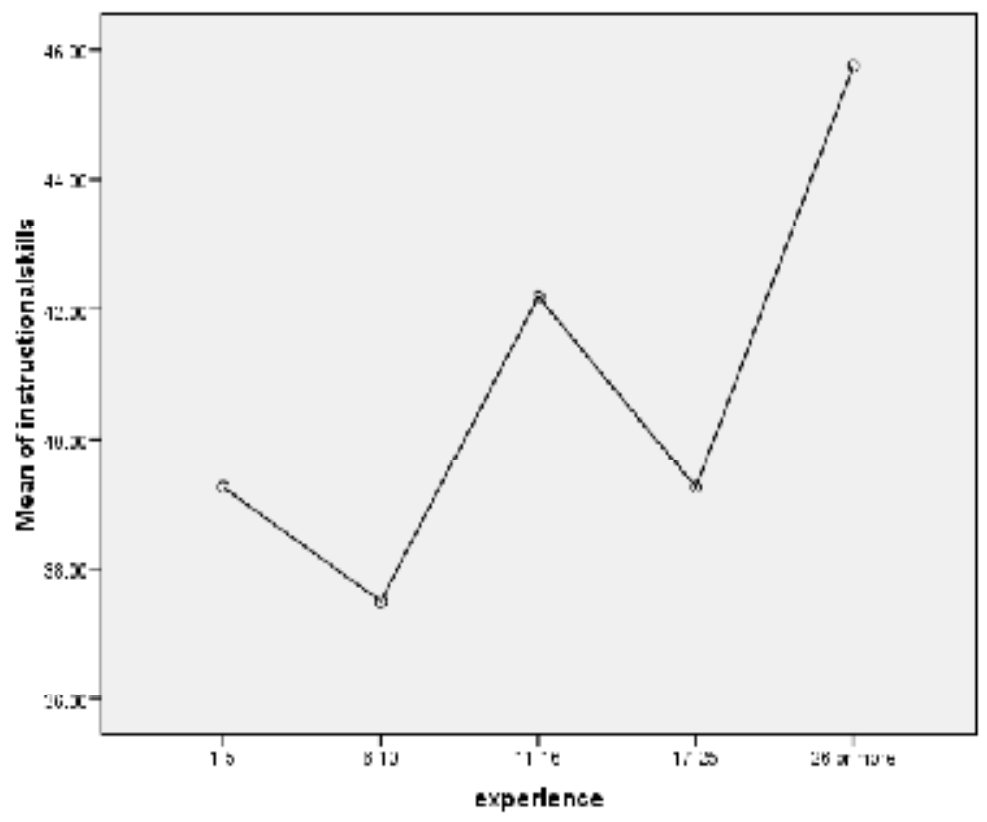

Figure 1: Experience and mean of instructional skills

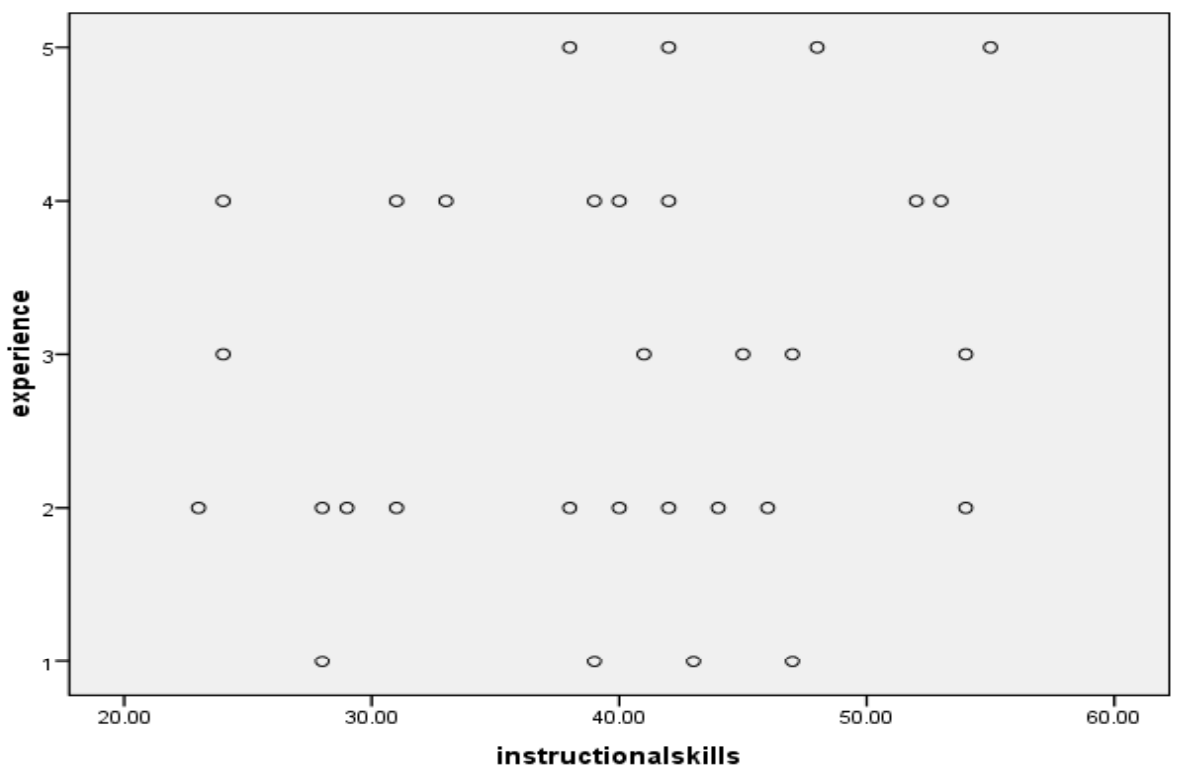

Figure 2: Instructional skills and experience 


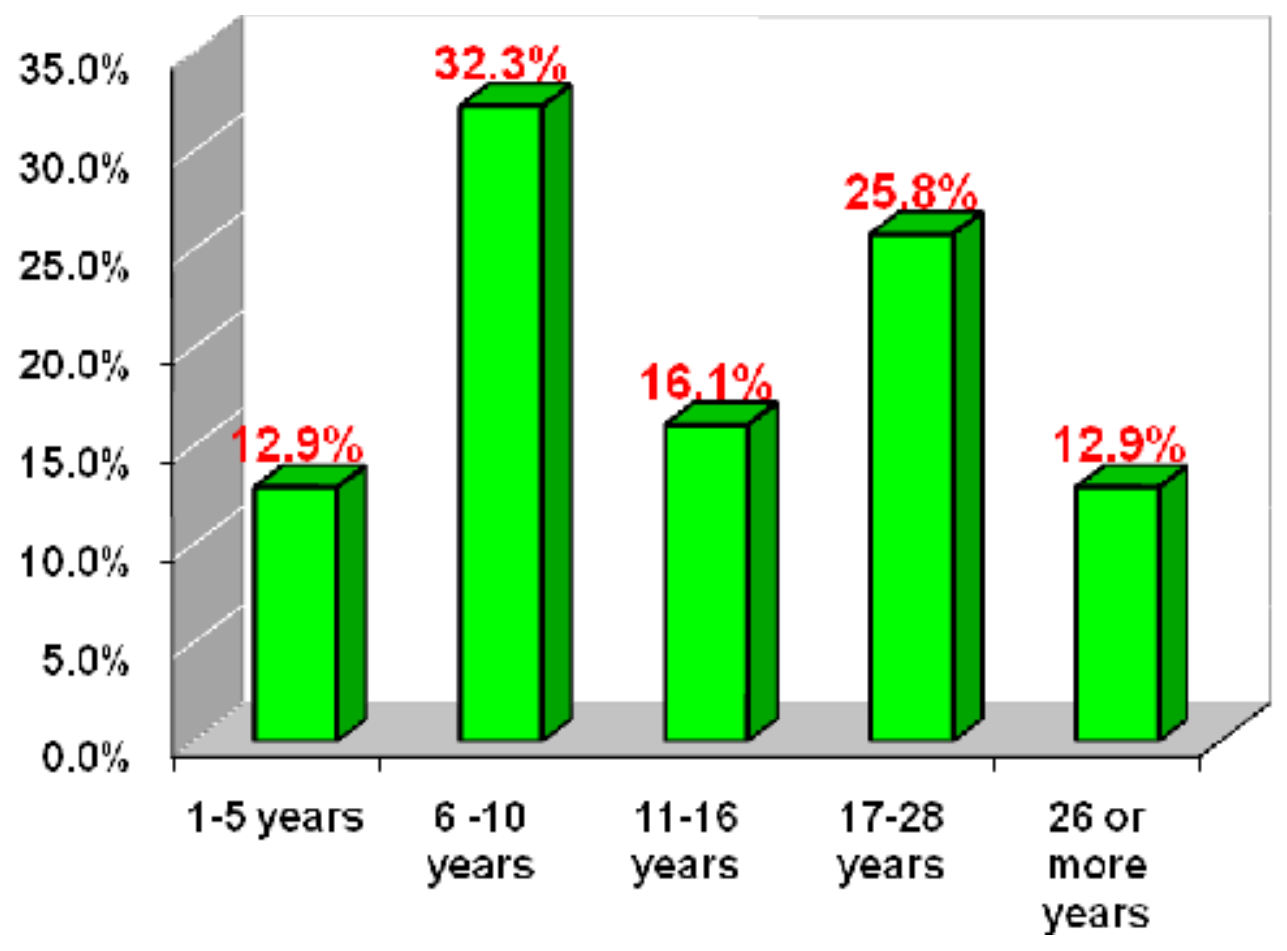

Figure 3: Frequency of samples

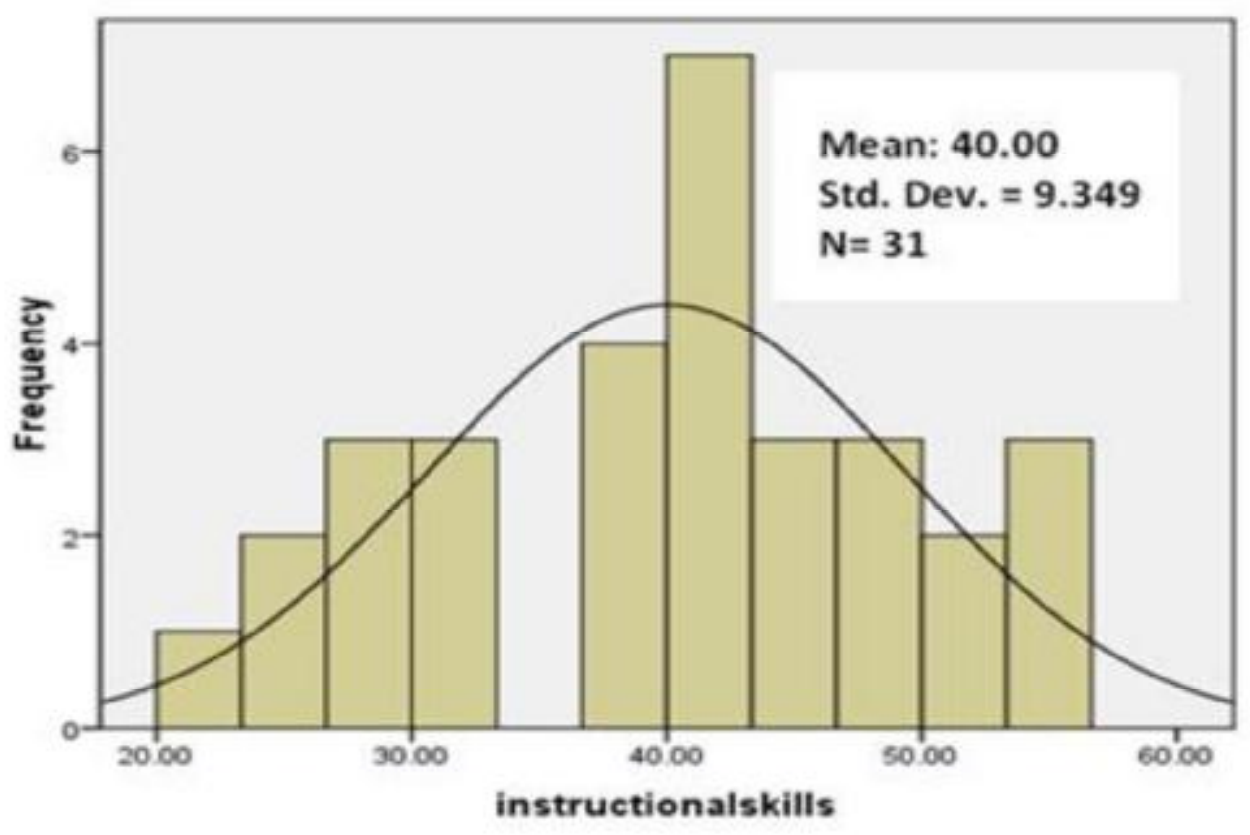

Figure 4: Histogram 


\section{Conclusion}

It is concluded that there is no relationship between working experiences and need for instructional skills. Therefore, being a novice, mid-experienced or experienced teacher is not of any proof to need or not need instructional skills. In fact the lecturers' working experiences do not have any effect (but may be related to) on need for instructional skills. Sometimes if a teacher teaches and the students do not comprehend it is not that the students are dumb. It is just that the teacher cannot convey what s/he has in mind to the students which might be due to not having enough instructional skills. Unfortunately, there are few training programmes for the teachers; moreover, there have not been many researches to see what knowledge and skills the teachers need to successfully teach the students and help them to learn effectively and guide them to the path they are supposedly willing to be on. Teachers are trainers. They have trainees. Trainees are flexible and will learn what they are told. It would be much better if our trainers are well trained before so that they can train well. If teachers (trainers) are not well trained, how are they going to be able to train in an acceptable and agreeable way?! Teachers are directly linked to the improvement of education which seeks change in roles and responsibilities and most importantly, skills. Therefore, it seems that all the teachers are to be challenged to obtain instructional skills without considering their working experience in terms of years. It is correct that experienced teachers and lecturers probably have enough experience in teaching, but on the other hand they need to gain instructional skills since they might be weak in some aspects of instructional skills. It would be of no harm if faculties evaluate the lecturers to see if they are qualified enough regarding instructional skills and to hold some in-service programs and courses for the lecturers regarding the weaknesses, the lecturers' needs and students' demands.

To be an effective teacher it is important to have commitment to one's own professional learning and development and a commitment to help students develop their learning in order to be professionals in their future jobs. This personal commitment can be looked into and given direction and resources through engaging in a range of professional development activities to improve. Professional development is more than just attending a workshop. It is also about evaluating your practices and considering students' feedback, reviewing the quality of learning that students demonstrate in the assessment tasks, working with colleagues on developing curriculum, attending teaching conferences, investigating and publishing aspects of your teaching experiences and participating and contributing to peer review on various dimensions of teaching practices. 


\section{Implication}

It seems a wise act if deans of faculties try to plan workshops or insist on having some classes for the faculty members to attend and improve their knowledge of how to instruct the class so that the students can benefit the most and really understand the depth of the specific subject the teachers is teaching. If this can be fulfilled, then students will have better opportunities to have the expertise in what they are learning which later on lead to action in real world. Holding some classes for instructional skills improvement will have benefits such as:

- Working closely with peers and colleagues to improve their knowledge from each other's experiences and skills

- Different instructional strategies and techniques will be practiced and mastered

- A positive learning environment with no stress and tension will be recognized

- Teachers' knowledge will be increased

- Teachers will be writing useful and "tangible" practical lesson plans

- Later, teachers can teach and inform their students expectations and intentions by using learning objectives

- Teachers will be aware of students needs in learning

- Teachers can be able to instruct the class more professionally

- Teachers will be more aware of the limitations and difficulties of students' learning processes

- Teachers will be receiving feedback from other colleagues and can try to improve themselves 


\section{References}

Azin-Manley, M., Sachse, T. \& Olson, C. (1996, October). Staff development needs assessment survey. Cheyenne, WY: Wyoming State Department of Education

Baker, M., \& Malle, S. (1995). A comparison of undergraduate major and technical knowledge of postbaccalaureate teacher candidates. The Journal of Agricultural Education and Extension, 2(3), 51-58.

Bauch, P. A., \& Goldring, E. B. (1998). Parent-teacher participation in the context of school governance. Peabody Journal of Education, 73, 15-35.

Blase, J. \& Blase J. (1998). Instructional leadership: How really good principals promote teaching and learning. Thousand Oaks, CA: Corwin Press.

Bradley, A. (1996, April 17). The missing link. Education Week, 7-13.

Brookfield, S. D. (1995). Becoming a critically reflective teacher. San Francisco: Jossey-Bass.

Clarke, B., James, C., \& Kelly, J. (1996). Reflective practice reviewing the issues and refocusing the debate. International Journal of Nursing Studies, 33(2), 171-180.

Dewey, J. (1933). Democracy and education. New York: Free Press.

Dormody, T. J., \& Torres, R. M. (2002). A follow-up study of agricultural education program graduates on teaching competencies. Journal of Agricultural Education, 43(4), 33-45.

Edwards, M. C., \& Briers, G. E. (1999). Assessing the in-service needs of entry phase agriculture teachers in Texas: A discrepancy model versus direct assessment. Journal of Agricultural Education, 40(3), 40-49.

Fitzharris, L. (1999). Curriculum development. Journal of Staff Development , 20, 30-31

Garton, B. L., \& Chung, N. (1996). The in-service needs of beginning teachers of agriculture as perceived by beginning teachers, teacher educators, and state supervisors. Journal of Agricultural Education, 37(3), 52-58.

Joerger, R. M. (2002). A comparison of the in-service education needs of two cohorts of beginning Minnesota agricultural education teachers. Journal of Agricultural Education, 43(3), 11-24.

Kisner ,Mary J .;Elliott ,Franklin E .; Foster, Pamela M.; Convington, Myrna A.; King, Marsha G.;Liou,Kun-I Tony,(1998). Professional Development Needs Assessment Survey Of In-service Clients Of the Center for Vocational Professional Personnel Development at the Pennsylvania State University., Press in the Pennsylvania State University.

Kolb, D. A. (1984). Experiential learning: Experience as the source of learning and development. Englewood Cliffs, NJ: Prentice-Hall.

Kotrlik, J. W., Redmann, D. H., Harrison, B. C., \& Handley, C. S. (2000). Information technology related professional development needs of Louisiana agriscience teachers. Journal of Agricultural Education, 4l(1), 18-29.

Layfield, K. D., \& Dobbins, T. R.(2002). In-service needs and perceived competencies of South Carolina agricultural educators. Journal of Agricultural Education, 43(4), 46-55.

Mundt, J. P., \& Connors, J. J. (1999). Problems and challenges associated with the first years of teaching agriculture: A framework for preservice and in-service education. Journal of Agricultural Education, 40(1), 38-48.

Peiter, $R$. L., Terry, R., Jr., \& Cartmell, D. D. II. (2003). Mentoring first year agricultural education teachers. Journal of Southern Agricultural Education Research, 53(1), 171-181.

Ponessa, J. (1996, April17). Union Dues. Education Week, 15-17.

Roberts, T. G., \& Dyer, J. E. (2002). Characteristics of effective agriculture teachers. Proceedings of the 29th National Agricultural Research Conference. Retrieved July 16, 2004, from: http://aaaeonline.ifas.ufl.edu/NAERC/2002/ naercfiles/NAERC/Characteristics\%20Robe rts-Dyer.pdf

Schön, D. A. (1983). The reflective practitioner: How professionals think in action. NewYork: Basic Books.

Schön, D. A. (1996). Educating the reflective practitioner: Toward a new design for teaching and learning in professions. San Francisco: Jossey-Bass.

Trzcinka, S. M. (1998). Curriculum and teachers' attitudes: The impact of the change process in especial education. Advances in Special Education, 11, 127-146.

Wall, R., \& Rinehart, J. R. (1998). School-based decision making and the empowerment of secondary school teachers. Journal of School Leadership, 8, 49-64.

Washburn, S. G., King, B. O., Garton, B. L., \& Harbstreit, S. R. (2001). A comparison of the professional development needs of Kansas and Missouri Teachers of Agriculture. Proceedings of the $28^{\text {th }}$ Annual National Agricultural Education Research Conference. 396-409. 